\title{
A Landscape View of Literacy Studies in Canada
}

\author{
BURCU YAMAN NTELIOGLOU \\ Brandon University
}

JENNIFER ROWSELL

Brock University

Over a hundred literacy researchers gathered at the University of Victoria for the $10^{\text {th }}$ annual Language and Literacy Researchers of Canada (LLRC) preconference, Writing the Past: Reading the Future. The preconference invited scholars to explore the landscape of literacy studies and present papers and engage in discussions and debates about where we have been, where we are, and where we are going as a field. Building on the momentum of this event, we have come together as organizers of the preconference with this special issue that brought together a number of Canadian scholars' work in diverse areas of literacy education from adult literacy to digital literacies, multiliteracies, Canadian Aboriginal children's literature and family literacy programs.

The five papers in this issue explore literacy learning across a range of in-school and out-of-school contexts illustrating the complex, multiple, layered and dynamic nature of literacies in our everyday lives. The first three papers come from our conference panelists and review the authors' past and current research as well as their considerations for future research. Suzanne Smythe presents a review of 10 years of adult literacy policy and practice in Canada. Smythe draws on the concepts of 'policy networks' (Hamilton, 2014), 'powerful literacies' (Crowther, Tett, \& Hamilton, 2012) and 'workaround' (Campbell 2012; Debono et al. 2013) to analyze policy texts and discourses. She discusses the tensions between the centrally imposed accountability structures and policy priorities, contrasted with the actualities of local educational contexts. She argues that educators and learners "participate in policy networks as powerful actors" and that definitions of literacy are constantly shaped and re-shaped though this interaction of texts, discourses, power, and agency.

Lynne Wiltse's paper offers a critical reflective narrative focusing on Aboriginal children's literature in Canada. Drawing on Aldana (2008) and Bothelho and Rudman's (2009) work, Wiltse analyzes her research, teaching and learning experiences using the three metaphors of "books that are mirrors", where students see themselves and their realities reflected; "books that are windows", which offer insights to Others' worlds; and "books that are doors", which invite readers to social action. Wiltse discusses the importance of considering cultural diversity in relation to text selection in K-12 classrooms as well as in teacher education programs, and stresses the value of using these texts that confront the status quo or the mainstream ideology and bring issues of social inequities to the forefront so that students and teachers can engage in critical discussion. Wiltse draws on the notions of 'difficult knowledge' (Pitt \& Britzman, 2006) and 'pedagogy of discomfort' (Boler, 1999; Boler \& Zembylas, 2003) as she examines the challenges and the role that discomfort plays while teachers and students explore difficult issues such as oppression, marginalization and social inequity. 
Questions of identity and representation, and building strong school-community relationships are also important areas of focus in the paper co-authored by Jim Anderson, Ann Anderson and Alison Gear. The authors share data from three different research studies that take place in diverse communities in Canada. Through these studies they illustrate the significance of designing family literacy programs based on unique cultural, linguistic and social needs of the community and the participants. The first study is a family literacy program in a largely working class small rural community in eastern Canada - a longitudinal study focusing on engaging parents in the development of young children's early literacy skills. The original study takes place in late 1980s and 20 years later the researchers reconnect with the community to study parents' retrospective views of their experiences in the program. The second study from which they draw is a mixedmethods research project exploring the experiences in a family literacy program with particular attention to students' linguistic diversity and second language pedagogy in a culturally and linguistically diverse metropolitan area of western Canada. The third study uses indigenous methodology and pays particular attention to power dynamics and collaborative knowledge production while examining a community-based family literacy program in a First Nations, Haida, community in north-western Canada.

Suzanna So-Har Wong documents the experiences of preschoolers' home multiliteracy practices in her study. Using Green's $(1988,2012)$ three-dimensional (3D) model of literacy as an analytical tool, Wong investigates children's engagement with digital technologies at home, taking account of how children use information and communication technologies to negotiate and represent meaning. In line with previous scholarship regarding multimodality and digital literacies, Wong argues that digital technologies such as iPads afford new ways of working with multiple modes of texts where children have the opportunity to become active producers of knowledge in out-ofschool contexts.

Using complexity theory (Davis \& Sumara, 2010, 2008) as a methodological frame, Linda Laidlaw and Joanne O'Mara discuss the potentials of digital technologies in the literacy development of children who have disabilities or learning differences. They raise important issues regarding the use of digital technologies in the classroom, and address the question: "Does it really matter if not all children learn how to use a pencil properly, but instead use digital forms of writing?" Sharing data from their collaborative study, they examine multimodal and digital practices in elementary classrooms, with particular attention to teacher and school resistance to using digital tools for text composition.

We are pleased to present these five thought-provoking papers that revisit and envision literacy in the face of tremendous changes, technological advances, increased diversity and globalization in Canada.

\section{Acknowledgements}

As the editors of this special issue we would like to thank all of our reviewers for their time and valuable feedback. 


\section{References}

Aldana, P. (2008). Books that are windows, Books that are mirrors: How we can make sure that children see themselves in their books [Speech transcript]. Retrieved from http://www.ibby.org/index.php?id=1008

Botelho, M., \& Rudman, M. (2009). Critical multicultural analysis of children's literature: Mirrors, windows, and doors. New York: Routledge.

Boler, M., \& Zembylas, M. (2002). Discomforting truths: The emotional terrain of understanding difference. In P. P. Trifonas (Ed), Pedagogies of difference: Rethinking education for social change (pp.110-136). New York: Routledge Falmer.

Campbell, D. (2011). Policy workaround stories are valuable evaluative indicators: But should they be told? American Journal of Evaluation, 32(3), 408-417.

Crowther, J., Tett, L. \& Hamilton, M. (2012). More powerful literacies. NIACE: England and Wales.

Davis, B., \& Sumara, D. (2010). 'If things were simple...': Complexity in education. Journal of Evaluation in Clinical Practice, 16, 856-860. doi: 10.1111/j.13652753.2010.01499.x

Davis, B., \& Sumara, D. (2008). Complexity as a theory of education. Transnational Curriculum Inquiry, 5(2). Retrieved from http://nitinat.library.ubc.ca/ojs/index.php/tci

Debono, D. S., Greenfield, D., Travaglia, J. F., Long, J. C., Black, D., Johnson, J., \& Braithwaite, J. (2013). Nurses' workarounds in acute healthcare settings: A scoping review. BMC Health Services Research, 13(1), 1-16.

Green, B. (1988). Subject-specific literacy and school learning: A focus on writing. Australian Journal of Education, 32(2).

Green, B. (2012). Subject-specific literacy and school learning: A revised account. In B. Green \& C. Beavis (Eds.), Literacy in 3D: An integrated perspective in theory and practice (pp. 2-21). Camberwell, VIC: ACER.

Hamilton, M. (2014). Global, regional and local influences on adult literacy policy in England. Globalisation, Societies \& Education, 12(1), 110-126. doi:10.1080/14767724.2013.858993

Pitt, A. \& Britzman, D. (2006) Speculations on qualities of difficult knowledge in teaching and learning: An experiment in psychoanalytic research. In K. Tobin \& J. Kincheloe (Eds.), Doing educational research: A handbook (pp. 379-401). New York: Sense. 